\title{
New geophysical and geotechnical approaches to characterise under utilised earthworks
}

\author{
D.A. Gunn, H.J. Reeves \& J.E. Chambers \\ British Geological Survey, Keyworth, UK
}

G. Ghataora, M. Burrow, \& P. Weston

Birmingham University, Birmingham, UK

J.M. Lovell

Soil Mechanics Ltd., Leamington Spa, UK
L. Nelder

Scott Wilson Ltd., Nottingham, UK

D. Ward

Lankelma Ltd., East Sussex, UK

R. Tilden Smith

Great Central Railway Ltd., Leamington Spa, UK

\begin{abstract}
Transferring the freight burden from road to rail would bring about many environmental benefits. The Rail Contribution to the Energy Review (Dept. for Transport 2006) indicated that rail freight produces eight times less $\mathrm{CO}_{2}$ per tonne.km than road freight. Implementing this strategy successfully will require further development of rail infrastructure to cope with additional capacity. Many new proposals, such as the EuroRail Freight Route, would utilise redundant and under-used infrastructure, much of which was constructed during the latter part of the nineteenth century. Earthworks of this age should be regarded as unique if they are to be improved or upgraded. Such upgrades would require investigations into the condition of the existing earthworks to assess the materials, variability in the geotechnical properties and engineering performance along the proposed route. This paper presents a section of embankment from the Great Central Railway as a case history that demonstrates the integration of a number of geophysical and geotechnical data to assess the condition of an embankment in relation to fill materials and track geometry. It emerged that embankment structure and strength information can be provided via combined use of non-intrusive mechanical and electrical techniques such as continuous surface wave profiling and resistivity surveying. It is envisaged that this information can be used to strategically plan intrusive investigations and works to improve the infrastructure.
\end{abstract}

\section{INTRODUCTION}

The Rail Contribution to the Energy Review (Dept. for Transport 2006) indicated that rail freight produces eight times less $\mathrm{CO}_{2}$ per tonne.km than road freight. Successfully transferring freight from road to rail will require additional rail infrastructure to cope with additional capacity. As an example, the EuroRail Freight Route (2006) project proposes a network through the central spine of the UK linking the Channel Tunnel to Glasgow. It would utilise redundant and under-used infrastructure, much of which was constructed during the latter part of the nineteenth century. In those pioneering times, standards in track gauge and geometry, and cutting and embankment profiles were developed empirically based upon observations of engineers progressing the works. Observations of the behaviour of embankment materials aided the construction of earthworks well before the scientific fundamentals of soil mechanics were developed. Consequently many earthworks, especially those constructed in Victorian times, should be regarded as unique if they are to be improved or upgraded. Such processes would require investigations into the condition of the existing earthworks to assess the materials and variability in the geotechnical properties, and engineering performance along the proposed route.

Standard site investigation techniques such as drilling and pitting can be augmented by combined geophysical and geotechnical surveys to identify fill materials, and the scale of variability in their properties and distribution. Material property information can be provided via several means, such as: direct installation of probes (Gunn \& Stirling 2004; Gunn et al. 2004; Nelder et al. 2006), portable, nonintrusive methods (Sussman et al. 2003; Clark et al. 2003; Gunn et al. 2005; Gunn et al. 2006a; Gunn et al. 2007), and from track-recording vehicles gathering related data (McAnaw 2001).

This paper presents a section of embankment from the Great Central Railway as a case history that demonstrates the integration of a number of geophysical and geotechnical data to assess the condition of an embankment in relation to fill materials and track geometry. The approach shows how traditional techniques can be augmented with developing techniques such as continuous surface wave and resistivity surveying to provide information through the complete earthworks. It is envisaged that the techniques used can also provide information for the 
design of works required to improve the infrastructure.

\section{EAST LEAKE EMBANKMENT RESEARCH SITE (ELERS)}

The Great Central Railway was originally constructed in the 1890s as a link from the Manchester, Sheffield and Lincolnshire railway to London (Bidder 1900, Fox 1900). The section of line used in this study serves as a goods link from the mainline at Loughborough to the gypsum works at East Leake. Daily traffic includes two freight locomotives operated by EWS Railway Ltd. and GB Rail Freight Ltd. The line is managed by the Great Central Railway (Nottingham) Ltd., the Nottingham Transport Heritage Centre and the Mainline Steam Trust. The current investigation focuses on a section of earthworks SW of East Leake, Nottinghamshire (Fig. 1), which were constructed using local materials excavated from adjacent cuttings to the SW and NE. The material was tipped and then compacted by subsequent movement of shunting locomotives and tipping wagons across the tipped material. The tipping method used along this section of the line was not stated explicitly by Bidder (1900), but has been deduced to have been end tipped from current observations and the information recorded by the engineers practicing at the time.

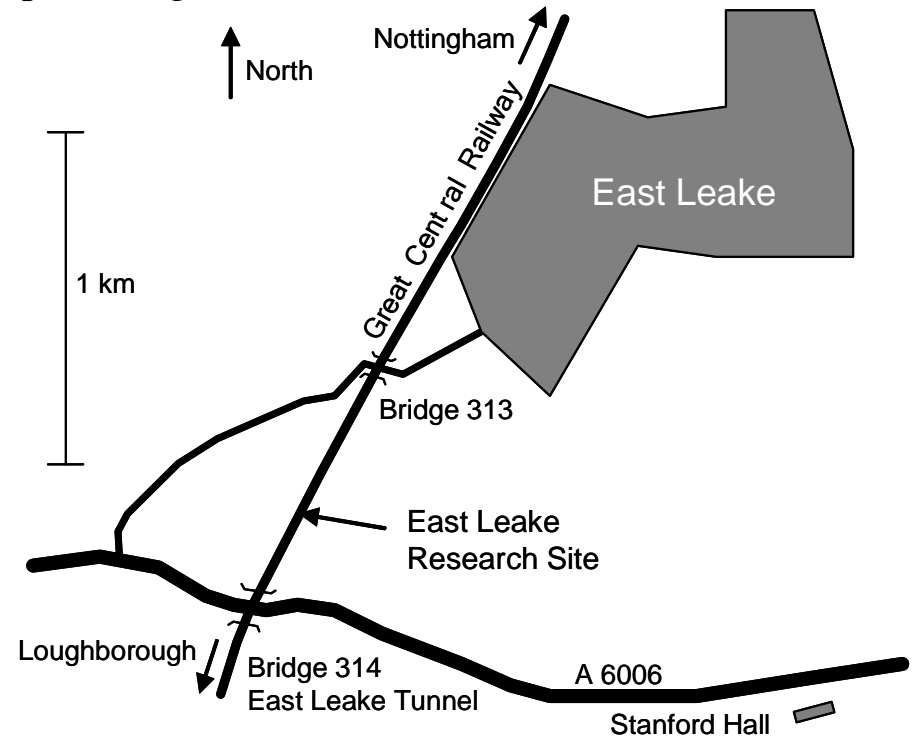

Figure 1. Site location: East Leake, South Nottinghamshire.

This section of embankment from the East Leake Tunnel (bridge 314) in the SW to the overbridge (bridge 313) in the NE forms the East Leake Embankment Research Site (ELERS). The site has been the subject of field investigations since September 2005. Victorian earthworks are generally very heterogeneous because of the techniques used in their construction, such as end tipping. Several of the data gathered from the field investigations can be integrated to provide an assessment of embankment condition in terms of the variability of fill materials. The scale of apparent heterogeneity observed is affected by the volume of ground sampled or sampling interval, (eg. probe spacing etc.). This study shows how a suite of rapid geophysical and geotechnical surveys can be combined to investigate potential larger scale features and lateral continuity of structure within the embankment, identify changes in fill regime and show the effect on track geometry. On the basis of these results recommendations are made for applying these survey techniques to evaluate the condition of existing earthworks as part of an upgrade scheme for re-introduction into the network.

\section{SITE INVESTIGATION TECHNIQUES}

Information on the physical and geotechnical property distribution within earthworks can be gathered from geophysical and geotechnical survey data respectively. A number of well understood relationships exist between geophysical properties such as resistivity (Rhoads et al. 1976; Mualem \& Friedman 1991; Jackson et al. 2002, Chambers et al. 2004; Friedel et al. 2006) and dielectric constant (a key parameter in radar surveys) (Davis \& Annan 1989; Baker 1991; Gallagher et al. 2000; Sussmann et al. 2003; Neal 2004) to lithology and moisture content. By combining geotechnical and geophysical data, it is possible to relate mechanical or engineering properties to lithological and moisture variation. This can be used as a basis for assignation or classification of the condition of earthworks.

The investigation at East Leake has included a series of intrusive and non-intrusive techniques comprising:

\section{Intrusive}

i. static cone penetration resistance tests (sCPT) to a depth of $10 \mathrm{~m}, \mathrm{~W}$ side of embankment,

ii. dynamic cone penetration resistance tests (dCPT) to $3 \mathrm{~m}$; W, E sides and between rails,

\section{Non-intrusive}

iii. continuous surface wave surveys (CSW) to ascertain shear wave velocity and small strain stiffness logs to $8 \mathrm{~m}$ depth, W, E sides and between rails,

iv. Falling weight deflectometer (FWD) tests, profile on $\mathrm{W}$ side of rails and at depth in trial pits, v. ground penetrating radar surveys (GPR), profiles along $\mathrm{E}, \mathrm{W}$ sides, between rails and transects across embankment,

vi. resistivity surveys, profiles along $\mathrm{W}$ side and transects across embankment. 
The sCPT technique (Meigh 1987, Soil Mechanics 2007) uses a cylindrical cone, pushed vertically from a rig into the ground at a constant rate of penetration of $20 \mathrm{~mm}$ per second. During penetration, measurements are made of the cone resistance, the side friction against the cylindrical shaft and, in piezocone tests, the pore water pressure generated at penetration by the cone. The dCPT technique uses a cone of known area driven into the ground with blows from a standard hammer onto the head of a piston or anvil attached to the cone by a set of steel rods. Commercial equipment is instrumented such that speed of impact and the penetration per blow are measured and used to calculate dynamic cone resistance using the Dutch formula (Langton 1999).

The CSW technique uses sinusoidal surface waves generated by an electromagnetic vertical vibrator seated on the ground surface. In practice, this produces a series of finite duration pulses, each at a single frequency over a range of frequencies, for example from $5 \mathrm{~Hz}$ to $100 \mathrm{~Hz}$ in increments of $0.5 \mathrm{~Hz}$ or $1 \mathrm{~Hz}$. Field data acquisition at each frequency is synchronized with the control to the vibrator. Field dispersion curves are generated from the recorded signals at two or more receivers using a method based on the steady state Rayleigh method described by Viktorov (1967) and Richart et al. (1970). The CSW technique is particularly suited to railway sites where ambient noise levels are high, and the field data are interpreted to provide a stiffness-depth profile (Zagypan \& Farifield 2000, Gunn et al. 2006a).

FWD systems have been mounted on trolleys for use on the railways and are operated by companies such as Scott Wilson Ltd. More recently, lightweight devices, such as the Prima 100 have been operated by companies such as Soil Mechanics Ltd., which allow single man operation without the need for a rail mounted vehicle. They provide a means of simulating axle loads on a single sleeper and of measuring the strain within the ballast with sub-millimetric accuracy (Grainger et al. 2001, Brough et al. 2003). Results can be presented either as measured deflection data or processed to provide performance indicators such as ballast strain factor or trackbed compression, the latter being used to calculate the effective stiffness of the trackbed at a given sleeper location.

GPR uses a transmitting antenna to provide a short pulse of high frequency (25 - $1000 \mathrm{MHz}$ ) electromagnetic energy into the ground. Variations in the electrical impedance within the ground generate reflections that are detected at the ground surface by the same or another antenna attached to a receiver unit (Davis \& Annan, 1989). Variations in electrical impedance are largely due to variations in the relative permittivity or dielectric constant of the ground, and thus respond well to water distribution, fill materials and layered structure (Neal 2004).
The resistivity technique uses an array of four electrodes (Telford et al. 1976), where two electrodes pass a direct or a low frequency alternating current into the earth while a potential difference is measured between the other two. The ratio of the voltage between any two voltage electrodes and the current flowing from a current source electrode to a current sink electrode is measured by the field resistivity equipment to provide an apparent resistivity of the ground.

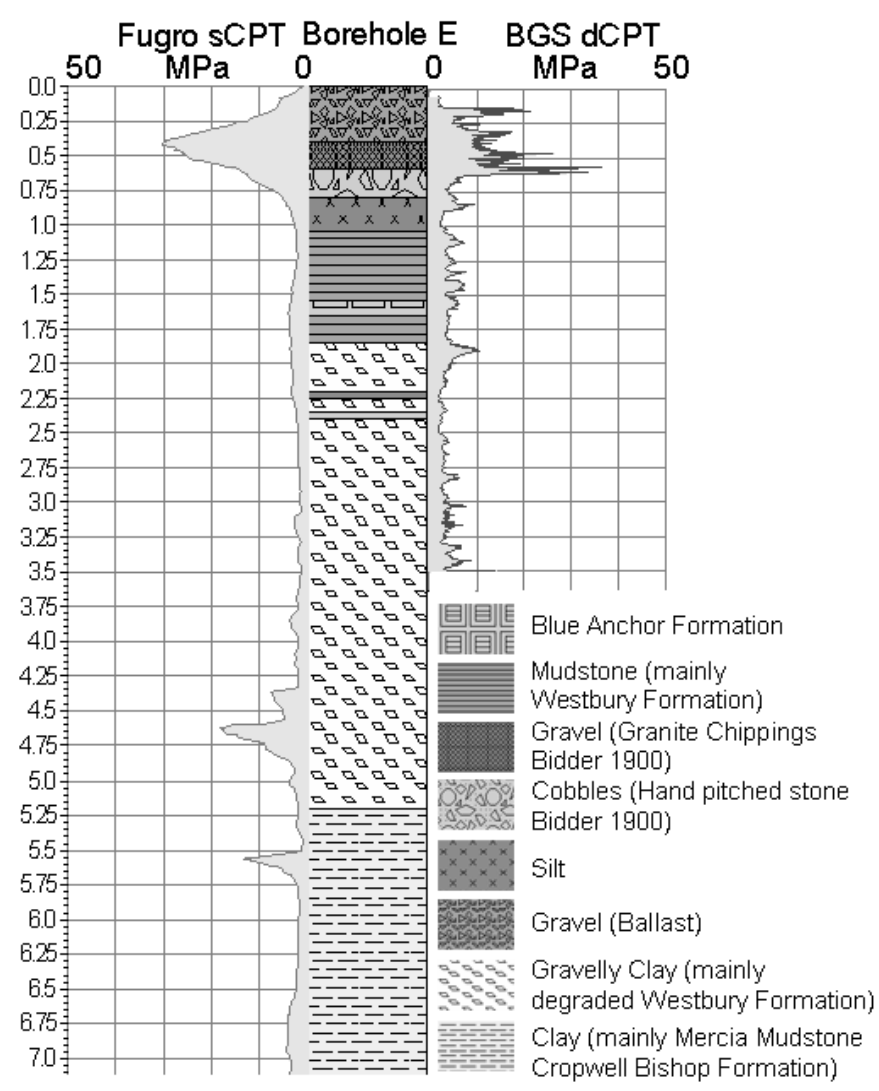

Figure 2. Comparison of a static and dynamic CPT through the embankment.

\section{ASSESSMENT OF EMBANKMENT CONDITION}

\subsection{Earthworks Materials}

Figure 2 shows an example of sCPT $\left(15 \mathrm{~cm}^{2}\right.$ cone area) and dCPT (2 $\mathrm{cm}^{2}$ cone area) profiles through the earthworks plotted with a log of the materials encountered. sCPT qnet values up to $30 \mathrm{MPa}$ in the upper ballast coincide with the upper layer of the original ballast pavement described by Bidder (1900). Generally, values range from $2 \mathrm{MPa}$ to 3 $\mathrm{MPa}$ in the underlying embankment fill with the occasional peak, e.g. up to $18 \mathrm{MPa}$ at $4.6 \mathrm{~m}$ depth in the mudstone fill derived from the Westbury Formation. Siltstone layers (e.g. between $2.25 \mathrm{~m}$ and 2.5 $\mathrm{m})$ are likely to be fragments of material, broken by the excavation and tipping process, rather than intact layers. The dCPT profile penetrated to a shallower depth due to manual deployment. Generally, the two CPT logs are similar, but the dCPT with a smaller 
cone area is more responsive to a finer scale of soil heterogeneity. This can be observed as greater detail on the log plot, for example, by the series of small peaks to 7.5 $\mathrm{MPa}$ in the mudstone fill from 1 $\mathrm{m}-1.5 \mathrm{~m}$ and the $10 \mathrm{MPa}$ peak in the gravelly clay fill (reworked Westbury Formation) at $1.9 \mathrm{~m}$. The materials from $0.4 \mathrm{~m}-0.8 \mathrm{~m}$ form the original engineered ballast pavement described by Bidder (1900) and GPR surveys show this pavement to be extensive across the embankment (Gunn et al. 2007). It appears as a strong continuous reflector at approximately $0.5 \mathrm{~m}$ depth on the $\mathrm{W}$ side of the embankment, but as a highly disrupted reflector along between the rails. This disruption is possibly a recent phenomenon related to the line taking very high train loads. The original ballast comprises 'hand pitched stone' overlain by 'granite' chippings', Bidder (1900), which on inspection, are coated with a layer of soft, red-brown clay. This clay-coated interface was coincident with high moisture content in contrast to the above materials and produced a strong reflection on the GPR profiles.

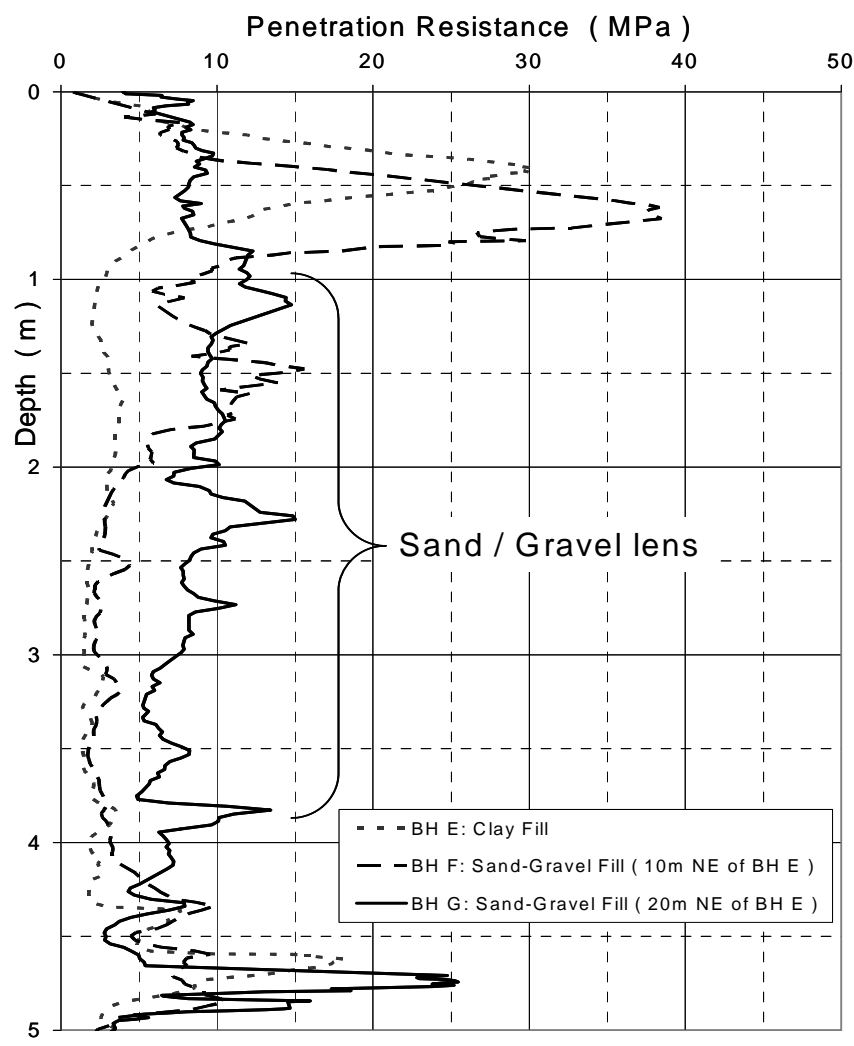

Figure 3. Example of a field and inverted small strain stiffness profiles with comparison to dCPT.

Figure 3 shows a field and inverted small-strain stiffness profile on the embankment fill predominately of reworked Westbury Formation from about $0.5 \mathrm{~m}$ depth. The stiffness is the product of the square of the shear wave velocity and the density where the density at all depths is estimated at $2.0 \mathrm{Mgm}^{-3}$. Below the upper layers of fill from $0.8 \mathrm{~m}$ depth, the earthworks fill mainly comprises a re-worked mudstone gravel of angular lithoclasts of the Westbury
Formation with sporadic cobbles of Blue Anchor Formation. The field data indicate that the ballast stiffnesses were around $100 \mathrm{MPa}$, while the subgrade was around $50 \mathrm{MPa}$ at $1 \mathrm{~m}$ rising to around 80 $\mathrm{MPa}$ at $5.0 \mathrm{~m}$ below the top of the sleepers. Generally, the inverted stiffness profile shows a good match to the field data except at the near surface where the field data are sparse. The inversion was allowed to ascribe high stiffness values to the ballast on the basis that very high penetration resistances were recorded in the materials of this layer during both static and dynamic cone penetration surveys. Gunn et al. (2006b) showed a correlation between higher shear wave velocities and higher dynamic cone penetration resistance values associated with gravel-rich lenses in cohesionless deposits at coastal sites. A nearby dynamic cone penetration resistance profile is shown for comparison, where high penetration resistances are associated with the ballast and particularly with the original ballast pavement.

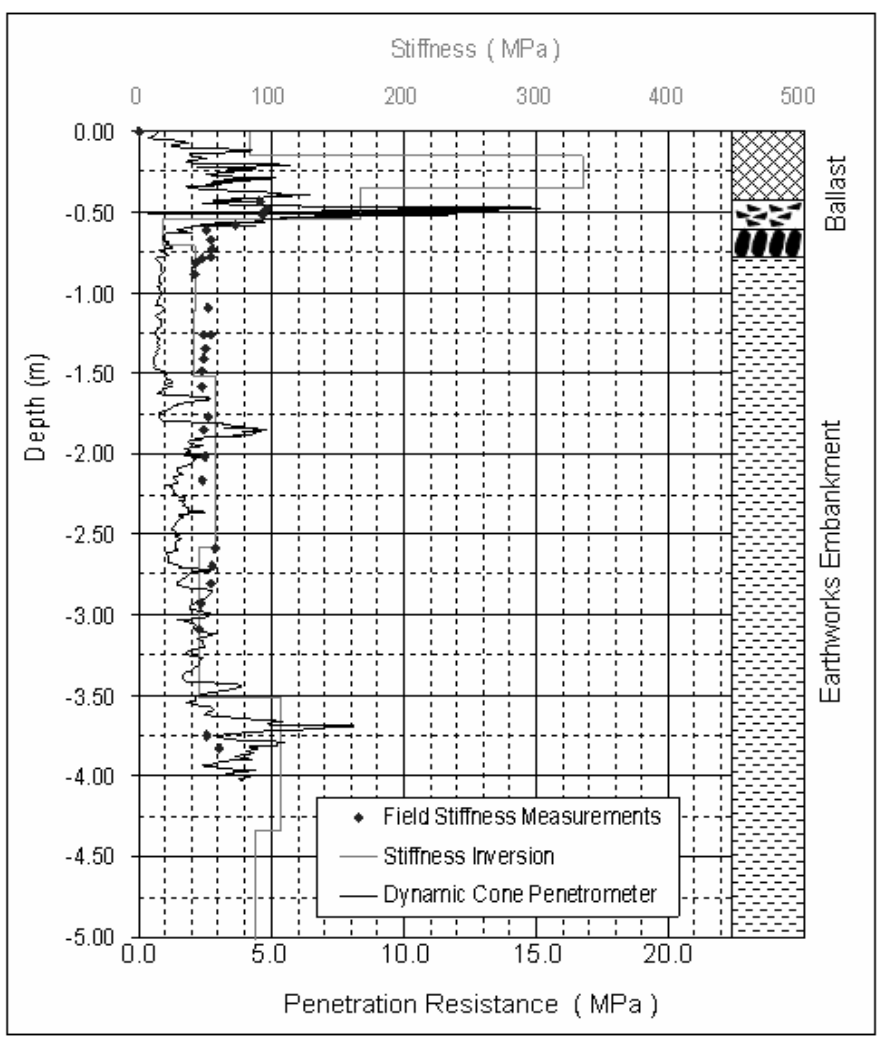

Figure 4. sCPT (qnet) profiles across interface between clay fill and sand / gravel lens.

\subsection{Embankment Profiles}

Nelder et al. (2006) and Gunn et al. (2007) presented 2D sections of the SCPT, dCPT, friction ratio and the CSW which were created by infilling a grid between successive depth logs using an anisotropic inverse distance weighting between neighbouring grid nodes. These were used to investigate potential larger scale lateral continuity of structure within the embankment. For example, features formed as exposed surfaces by trafficking or drying out, or, as a 
natural accumulation of large intact blocks in the early phase of embankment construction appear as bands with high penetration resistances up to 20 $\mathrm{MPa}$, which extend laterally for up to $30 \mathrm{~m}$ at around $5 \mathrm{~m}$ depth just above the top surface of the bedrock.

During construction of Victorian embankments the fill related directly to the material taken from adjacent cuttings (cut and fill). Consequently, Victorian embankments contain many interfaces between materials of differing engineering performance, which are very often associated with poor track geometry. Figure 4 shows the effect on penetration resistance within the embankment across an interface between clay (BH E: Clay Fill), and, sand and gravel fill (BH G: Sand/Gravel Fill). The clay comprises re-worked mudstone gravel derived from the Westbury formation and the sand and gravel comprises an upper zone to $2 \mathrm{~m}$ of sand and rounded gravels of glaciofluvial origin overlying a gravel of angular lithoclasts of Blue Anchor Formation, which extends to $4 \mathrm{~m}$ depth.

Stiffness values (MPa) from surface FWD tests (Prima 100 with $300 \mathrm{~mm}$ plate dia.) were 43.9, 41.2 and 47.1 at E, F and $G$ respectively. Further over the sand / gravel surface stiffness values were 26.3, 26.8 and 30.0 at 30, 40 and $50 \mathrm{~m} \mathrm{NE}$ of $\mathrm{BH}$ E respectively. It is suspected that these surface FWD tests provide a measure of the stiffness of the ballast at the near surface and that deeper information can be gained either by using a larger plate or by testing in trial pits. At $\mathrm{BH} \mathrm{E}$ a stiffness value of $80.3 \mathrm{MPa}$, measured at $0.4 \mathrm{~m}$ deep was considered to be representative of the original ballast layers, and a value of $36.8 \mathrm{MPa}$ at $0.8 \mathrm{~m}$ representative of the silt and mudstone at the top of the underlying earthworks. FWD tests at successive depths during pitting provide stiffness profiles to limited depths. However, prior to pitting or where pitting is restricted, a single CSW test from the surface will provide a stiffness profile through the whole earthworks; an insight that is useful for planning remedial works.

Very poor track geometry occurred over a $20 \mathrm{~m}$ interface zone across the clay-to-sand/gravel fill boundary. The development of poor geometry on the NE side is coincident with a thinning of the sand/gravel lens (Fig. 5). Resistivity measurements (Chambers et al. 2007) respond well to lithology and moisture content, and resistivity images aid site mapping of fill materials. The lens of fill comprising sand, gravel and siltstone produces a wedge shaped zone with resistivities above 150 Ohm.m. The wedge develops from the surface at about the $40 \mathrm{~m}$ station (BH E) and thickens to about the $50 \mathrm{~m}$ station (BH F) such that it extends from the surface to 4 $\mathrm{m}$ depth. This high resistivity wedge persists laterally over this depth interval towards the $80 \mathrm{~m}$ station.

\section{CONCLUSIONS}

An investigation at the East Leake Embankment Research Site was undertaken to provide an assessment of the structure, the geotechnical properties and the variability in a Victorian Embankment. This involved the gathering of geotechnical data via probing, drilling, core sampling and laboratory testing and geophysical data from surface geophysical surveys. This is directly applicable to the evaluation of the potential engineering performance of abandoned or regenerated rail routes in future programmes, such as the EuroRail Freight Route. This study indicated poor track performance at engineering interfaces, and again, highlights that the problem is related to the materials, condition, engineering properties and performance of the subgrade and underlying embankment. It is essential that such problems are identified and remedied as part of the process to upgrade or improve infrastructure to cope with increased traffic and load schedules.

It is envisaged that there are many interfaces between different engineering materials throughout the UK network where track performance will be poor. Geophysical and geotechnical surveys can be combined in an embankment condition assessment scheme that will assist in their location and charac-

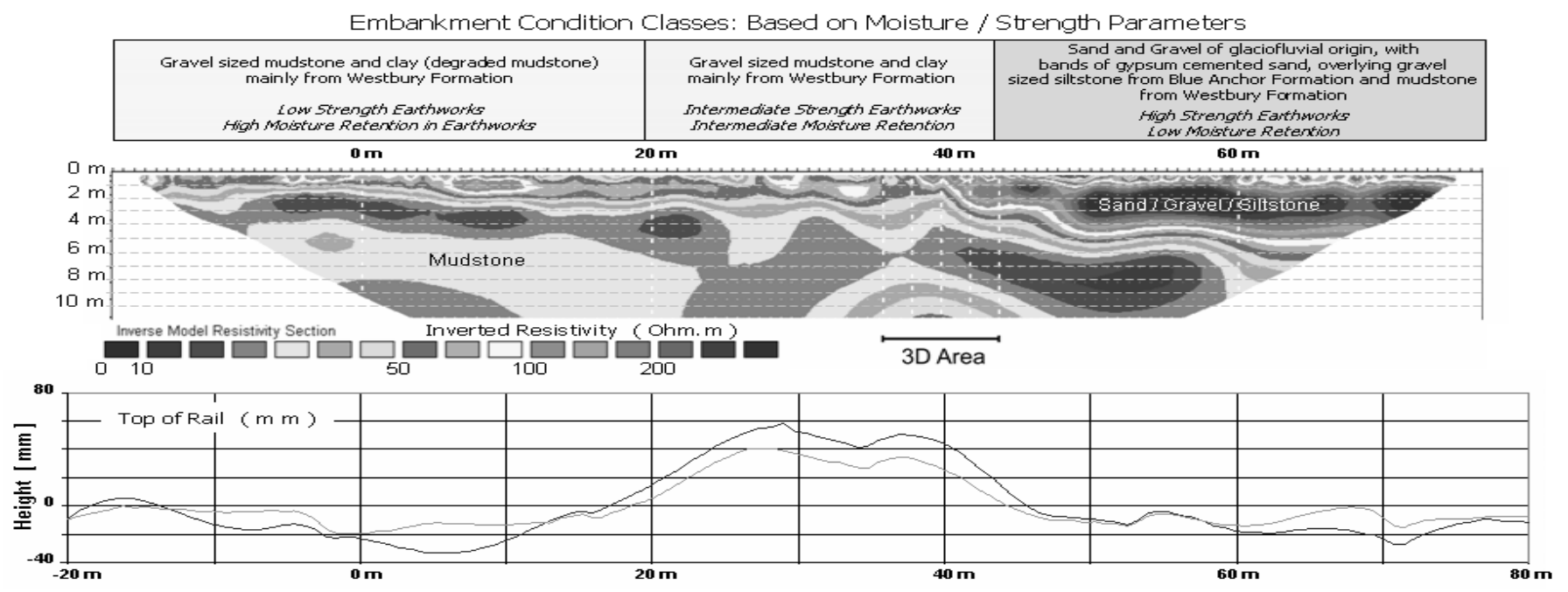

Figure 7. Longitudinal resistivity image compared to the track geometry and embankment condition. 
terisation, and also, aid the design of geotechnical remedial or improvement measures. All the techniques discussed in this case history can be applied to provide rapid coverage to rates of several hundred metres per day. The recommendations from this paper would be to plan the surveying of the network in a modular fashion to maximise the information gained and its use downstream. For example, reconnoitring / locating interfaces / subgrade problems using non-intrusive surface survey techniques including GPR and resistivity surveying, followed by combined techniques like CPT, CSW and FWD surveys to characterise materials, properties and variability in areas identified by large physical property contrasts on GPR and resistivity sections.

\section{ACKNOWLEDGEMENTS}

This paper is published with the permission of the Executive Director of the British Geological Survey (NERC).

\section{REFERENCES}

Baker, P.L., 1991. Response of ground penetrating radar to bounding surfaces and lithofacies variations in sand barrier sequences. Exploration Geophys. 22, pp19-22.

Bidder, F.W., 1900. The Great Central Railway Extension: Northern Division. ICE, Vol. CXLII, Session 1899-1900, Part IV, Paper 3227, pp 1-22.

Brough, M., Stirling, A., Ghataora, G., Madelin, K. 2003. Evaluation of railway trackbed and formation: a case study. NDT\&E Int. 36, pp 145-56

Chambers, J.E., Loke, M.H., Ogilvy, R.D. \& Meldrum, P.I. 2004. Noninvasive monitoring of DNAPL migration through a saturated porous medium using electrical impedance tomography. Jour. Contaminant Hydrology, (68), pp $1-22$.

Chambers, JE, Wilkinson, PB, Gunn, DA, Ogilvy, RD, Ghataora, GS, Burrow, MPN \& Tilden Smith, R. 2007. Non-Invasive Characterization and Monitoring of Earth Embankments Using Electrical Resistivity Tomography (ERT). Proc. 9th Int. Con. Railway Engineering, London.

Clark, M., Gordon, M. \& Forde, M. 2003. Issues over highspeed non-invasive monitoring of railway trackbed. NDT \& E Int. 37, (2), pp 131-139.

Davis, J.L. \& Annan, A.P., (1989). Ground-penetrating radar for high-resolution mapping of soil and rock stratigraphy. Geophysical Prospecting, 37, 531-51.

Department for Transport, 2006. Rail Contribution to Energy Review.

EuroRail Freight Route. 2006.

http://www.blugman.freeserve.co.uk/efr/index2.html

Fox, F.D. 1900. The Great Central Railway Extension: Southern Division. ICE, Vol. CXLII, Session 1899-1900, Part IV, Paper 3209, pp 23-48.

Friedel, S., Thielen, A. \& Sringman, S.M. 2006. Investigation of a sloe endangered by rainfall-induced landslides using $3 \mathrm{D}$ resistivity tomography and geotechnical testing. Jour. Appl. Geophys., (60), pp 100-114.

Gallagher, G., Leiper, Q., Clark, M. \& Forde, M. 2000. Ballast evaluation using ground penetrating radar. Railway Gazaette Int., 2000, pp 101-102.

Grainger, P.S., Sharpe, P. \& Collop, A.C. 2001. Predicting the effect of stiffness on track quality. Proc. 4th Int. Con. Railway Engineering, London.
Gunn, D.A, Nelder, L.M., Jackson, P.D. \& Entwisle, D.C, Stirling, A.B., Konstantelias, S. \& Lewis, R.W., Kingham, P. 2004. Geophysical inspection of the trackbed-subgrade stiffness and performance. Proc. 7th Int. Con. Railway Engineering, London.

Gunn, D.A. \& Stirling, A.B. 2004. Geophysical trackbed and subgrade monitoring at Leominster Station. Rail Technology Magazine, 4, (6), pp 34 - 37.

Gunn, D.A, Nelder, L.M., Chambers, J.E., Reeves, H., Freeborough, K., Jackson, P., Stirling, A.B. \& Brough, M., 2005. Geophysical monitoring of the subgrade with examples from Leominster. Proc. 8th Int. Conf. Railway Engineering, London.

Gunn, D.A., L.M. Nelder, J.E. Chambers, M.R. Raines, H.J. Reeves, D. Boon, S. Pearson, E. Haslam, J. Carney, A.B. Stirling, G. Ghataora, M. Burrow, R.D. Tinsley, W.H. Tinsley, R. Tilden-Smith. 2006a. Assessment of railway embankment stiffness using continuous surface waves. Proc. 1st Int. Conf. Railway Foundations, Birmingham, September 2006, pp94-106.

Gunn, D.A., S.G. Pearson, J.E. Chambers, L.M. Nelder, J.R. Lee, D. Beamish and J.P. Busby, R.D. Tinsley \& W.H. Tinsley. 2006b. An evaluation of combined geophysical and geotechnical methods to characterise beach thickness. Q.J.E.G.H. 39, 339-355

Gunn, D.A, Reeves, H., Chambers, J.E., Pearson, S.G., Haslam, E., Raines, M.R., Tragheim, D., Ghataora, G., Burrow, M, Weston, P., Thomas, A., Lovell, J.M., Tilden Smith, R., Nelder, L.M. 2007. Assessment of embankment condition using combined geophysical and geotechnical surveys. Proc. 9th Int. Conf. Railway Engineering, London

Jackson, P.D., Northmore, K.J., Meldrum, P.I., Gunn, D.A., Hallam, J.,Wambura, J.,Wangusi, B. \& Ogutu, G. 2002. Non-invasive moisture monitoring within an earth embankment - a presursor to failure. NDT \& E Int., 35, pp107-115.

Langton, D.D. 1999. The Panda lightweight penetrometer for soil investigation and monitoring material compaction. Ground Engineering, September, pp 33 - 37.

McAnaw, H.E. 2001. System that measures the system. Proc. 4th Int. Con. Railway Engineering, London.

Meigh, A.C. 1987. Cone penetration testing. Methods and interpretation. CIRIA Ground Engineering Report: In situ testing, Butterworths, London, 141p.

Mualem, Y. \& Friedman, S.P. 1991. Theoretical prediction of electrical conductivity in saturated and unsaturated soil. Water Resources Res., 27, (10), 2771-2777.

Neal, A. 2004. Ground-penetrating radar and its use in sedimentology: principles, problems and progress. EarthScience Reviews, Vol. 66, pp261-330.

Nelder, L.M., D. A. Gunn \& H. Reeves. 2006. Investigation of the Geotechnical Properties of a Victorian Railway Embankment. Proc. 1st Int. Conf. Railway Foundations, Birmingham, September 2006, pp 34-47.

Rhoads, J.D., Ratts, A.C. \& Pather, R.J. 1976. Effects of liquid phase electrical conductivity, water content and surface conductivity on bulk soil electrical conductivity. Jour. Soil Sci. America, 40, 651-655.

Richart F.E. Jr., Wood R.D. \& Hall J.R. Jr. 1970. Vibration of soils and foundations. Prentice-Hall, New Jersey.

Soil Mechanics Ltd. 2007. Geocone Homepage http://www.esgl.co.uk/soilmechanics/geocone/index.htm

Sussmann, T.R., Selig, E.T. \& Hyslip, J.P. 2003. Railway track condition indicators from ground penetrating radar. NDT \& E Int. 36, (3), pp 157-167.

Telford, W.M., Geldart, L.P., Sheriff, R.E. \& Keys, D.A. 1976. Applied Geophysics. London, Cambridge University Press, 860p.

Viktorov, I.A. 1967. Rayleigh and Lamb waves: physical theory and applications. Plenum Press, New York. 154p. 
Zagyapan, M. and Farifield, C.A. 2000. The use of continuous surface wave and impact techniques to measure the stiffness and density of trackbed materials. Proc. 3rd Int. Con. Railway Engineering, London. 